Research article

\title{
DIFFERENT PATHWAYS INVOLVED IN THE STIMULATORY EFFECTS OF HOMOCYSTEINE ON RAT DUODENAL SMOOTH MUSCLE
}

\author{
STOJANOVIĆ Marija ${ }^{1 *}$ ŚĆEPANOVIĆ Ljiljana ${ }^{1}$, MITROVIĆ Dušan ${ }^{1}$, \\ ŠĆEPANOVIĆ Vuk ${ }^{2}$, ŠĆEPANOVIĆ Radomir ${ }^{3}$, DJURIC Marko ${ }^{4}$, ILIĆ Slobodan ${ }^{5}$, \\ ŠĆEPANOVIĆ Teja ${ }^{6}$, DJURIC Dragan ${ }^{1}$
}

${ }^{1}$ Institute of Medical Physiology „Richard Burian“, Faculty of Medicine, University of Belgrade, 11000 Belgrade, Serbia; ${ }^{2}$ Institute for Neurosurgery, Clinical Center of Serbia, University of Belgrade, 11000 Belgrade, Serbia; ${ }^{3}$ Belgrade University of Defense, Military Medical Academy, 11000 Belgrade, Serbia; ${ }^{4}$ Department of Anaesthesiology, Reanimatology and Intensive Care, University Clinical Hospital „Dr Dragisa Misovic“, Belgrade, Serbia; ${ }^{5}$ University Children’s Hospital, University of Belgrade, 11000 Belgrade, Serbia; 'Institute of Neonatology, 11000 Belgrade, Serbia

(Received 21 July 2016, Accepted 03 February 2017)

Recent studies have confirmed that hyperhomocysteinemia is associated with gastrointestinal diseases; however, the direct effect of homocysteine on gastrointestinal reactivity still remains unknown. The aim of this study was to demonstrate how homocysteine may affect nitric oxide mediated duodenal relaxation and whether cholinergic receptors and $\mathrm{K}^{+}$channels take part in stimulating motility, as well as to explore whether oxidative stress is associated with homocysteine-mediated effects. Experiments were carried out on male rats, body mass 250-300 g. Two groups of animals were treated by i.p. application of saline and D,L-Hcy $(0.6 \mu \mathrm{mol} / \mathrm{g} \mathrm{bm})$. After $2 \mathrm{~h}$ of incubation, the duodenal segments were prepared for biochemical analysis and contractile response measurements in an organ bath with Tyrode's solution. Effects of TEA $(10 \mathrm{mmol} / \mathrm{L})$ and L-NAME $(30 \mu \mathrm{mol} / \mathrm{L})$ on duodenal contractility in the presence of D,L-Hcy $(0.6 \mu \mathrm{mol} / \mathrm{g} \mathrm{bm})$ were investigated. Elevated homocysteine levels seem to be of crucial importance for the deterioration of contractility through nitric oxide mediated relaxation, and, in part, by activation of $\mathrm{K}^{+}$channels. Hcy showed direct promuscarinic effects, since 30 min pretreatment of rat duodenum significantly enhanced the contractile effect of increasing concentrations of ACh $\left(10^{-9}-10^{-2}\right.$ $\mathrm{mol} / \mathrm{L}$ ). Catalase activity, superoxide dismutase, glutathione peroxidase and the total antioxidant system were reduced while the thiobarbituric acid-reactive substances level was elevated. Our data showed a consistent profile of gastrointestinal injury elicited by sulfur-containing amino acid-homocysteine. This could contribute to explain, at least in part, the mechanisms involved in human gastrointestinal diseases associated to hyperhomocysteinemia.

Keywords Contractility; Duodenum; Homocysteine; Oxidative stress; Rat

\footnotetext{
*Corresponding author: e-mail: mrj.stojanovic@gmail.com
} 


\section{INTRODUCTION}

Homocysteine (Hcy) is a sulfur-containing amino acid synthesized during transformation of methionine to cysteine in methionine metabolism [1]. Several observational studies have shown that a raised blood Hcy level - hyperhomocysteinemia (HHC) is a risk factor for cardiovascular events, including ischemic heart disease, chronic kidney disease and cerebrovascular disease [2,3].

Numerous clinical studies have shown that an elevated plasma homocysteine level might be an independent risk factor for gastrointestinal diseases. Recent data have explored the relation between HHC and inflammatory bowel disease (IBD) condition, and some authors have suggested an involvement of Hcy in the pathogenesis of these diseases [4,5]. Inflammatory bowel disease, including Crohn's disease (CD) and ulcerative colitis (UC), are a group of chronic intestinal disorders with a multifactorial etiology [6]. A study by Jiang et al. [7] showed that Hcy-related gene and metabolites are involved in the pathogenesis of UC. Increased homocysteine levels in the colonic mucosa and plasma of patients with IBD may play a role in the pathogenesis of $\mathrm{CD}$ and UC [8]. Evolution of CD can be riddled with intestinal and extra-intestinal complications, particularly atherothrombotic events [9]. However, the increased Hcy concentrations in patients with IBD may also be a consequence of the disease itself because the gastrointestinal tract is responsible for much of the metabolism of sulfur amino acids.

A proinflammatory role of Hcy in IBD was also suggested [10]. Hyperhomocysteinemia is relatively frequent in patients with celiac disease [11], and may be a risk marker for colorectal cancer, gastric cancer and increased colorectal carcinogenesis in IBD patients [12-14]. These findings lead us to investigate Hcy effects on the gastrointestinal system under laboratory conditions.

Literature data are controversialabout the effects of HHCongastrointestinalcontractility. Intestinal contractility is decreased in HHC due to matrix metalloproteinase-9 (MMP-9)-induced intestinal remodeling in mice colon [15]. Increased plasma Hcy concentration has been implicated in constipation (lowered fecal output), indicating that $\mathrm{HHC}$ itself may be causing gastrointestinal distress. Constipation as a motility disorder is common in the elderly. Lowering plasma levels of homocysteine in nursing home residents improved constipation [16].

It is well known that $\mathrm{NO}$ is released by non-adrenergic, non-cholinergic (NANC) inhibitory neurons in a variety of tissues, including gastrointestinal (GI) smooth muscles [17]. Nitric oxide synthesizing neurons are distributed extensively in the mysenteric and submucosal nerve networks of rats and humans [18-21]. Functional in vitro and in vivo studies provide convincing evidence in support of the notion that NO is released by NANC inhibitory motoneurons mediating relaxation of the mammalian gut [22-24]. 
Recent studies have suggested that part of the hyperpolarizing effects of NO may be mediated by stretch-dependent Kp (SDK) channels that are expressed in GI smooth muscles [25]. Previously was demonstrated that the sulfur-containing amino acid methionine acted as a specific blocker of stretch dependent potassium channels and nitrergic responses in the murine colon [26].

Hyperhomocysteinaemia has been suggested to be implicated in the imbalance between pro-oxidants and antioxidants linked to its pro-oxidant properties or in the impairment of antioxidant systems. Antioxidant defense is composed of enzymatic (superoxide dismutase - SOD, catalase - CAT, glutathione peroxidase - GPx), and non-enzymatic (vitamin $\mathrm{A}$, vitamin $\mathrm{E}$, vitamin $\mathrm{C}$, thiol antioxidants, albumin, bilirubin, uric acid) antioxidants [27]. Total antioxidant status (TAS) consists of all antioxidants present in body fluids. Lipid peroxidation, which is mediated by free radicals, is considered to be the major mechanism of cell membrane destruction and cell damage. Alteration in the oxidant - antioxidant profile is known to occur in IBD. Growing evidence suggests that HHC may promote chronic intestinal mucosa inflammation, mainly through oxidative stress [28-30]. Oxidative stress induces not only gastric mucosal injury, but also gastric motility dysfunction, such as diabetic gastroparesis. Gastroparesis is thought to be caused by ROS-induced damage of the networks of the interstitial cells of Cajal [31].

The aim of the current study was to test the hypotheses that a high level of homocysteine was associated with the digestive motility disorders by impaired NO-dependent relaxation of the gastrointestinal smooth muscle by activating SDK channels and by increasing oxidative stress. We also tested cholinergic receptors involvement in homocysteine effects.

\section{MATERIAL AND METHODS}

\section{Acute D,L-homocysteine administration}

Sixteen male adult albino rats (Rattus norvegicus) of the Wistar strain ( 3 months old) weighing $220 \pm 20 \mathrm{~g}$ were used. Four animals were housed per cage. Animals were acclimatized to standard animal laboratory conditions for five days (12:12-h light-dark cycle, temperature $22 \pm 2{ }^{\circ} \mathrm{C}$ and relative humidity $50 \pm 5 \%$ ). Rats were randomly divided into two groups of eight rats each for the control group $(\mathrm{C})$ and experimental group (EG). They received a single intraperitoneal (i.p.) injection of $1 \mathrm{ml}$ of saline (C) or $0.6 \mu \mathrm{mol} / \mathrm{g}$ body mass of D,L-homocysteine (EG). After incubation of 2 hours in standard laboratory conditions, the animals were sacrificed by decapitation and dissection of the duodenum was performed. Organ samples of both groups were immediately removed and prepared for biochemical assays and contractile response measurements. After the weight was measured, $0.5 \mathrm{~g}$ segments of tissue were homogenized in $5 \mathrm{ml}$ of phosphate buffer. The homogenates were centrifuged (10 min, $10000 \mathrm{rpm}$ ) and the clear supernatant was kept at $-20 \mathrm{C}^{\circ}$ for biochemical analysis (index of lipid peroxidation, total antioxidant status- TAS, CAT, SOD, GPx activity 
and acetylcholinesterase activity). The contractile response was obtained in the isolated organ bath.

\section{Isolated duodenum preparation}

As previously described, after $2 \mathrm{~h}$ incubation in the D,L-Hcy, duodenal segments of about $2 \mathrm{~cm}$ in length were quickly removed just distal to the pylorus and vertically suspended in a $50 \mathrm{ml}$ isolated organ bath filled with Tyrode's solution of the following composition (mM) : $\mathrm{NaCl} 136.9, \mathrm{KCl} 2.7, \mathrm{CaCl}_{2}$ 1.0, $\mathrm{NaHCO}_{3} 11.9, \mathrm{NaH}_{2} \mathrm{PO}_{4} 0.4$ and glucose 5.6. The solution was maintained at $36 \pm 1{ }^{\circ} \mathrm{C}$ and gassed with a mixture of $\mathrm{O}_{2}(95 \%)$ and $\mathrm{CO}_{2}(5 \%)$ at atmospheric pressure. After an equilibration period of $30 \mathrm{~min}$, contractile responses were recorded with an isometric transducer connected to a Sensor Medics Dynograph R511A recorder. Preparations were placed under a resting tension of $1 \mathrm{~g}$. Tissue responses (resting tone, amplitude of contractions) were measured as changes in isometric tension of the duodenum. The responses were than calculated and expressed in milligrams (mg). Frequency of contractions was calculated as the number of contractions per minute.

Cumulative concentration-contractile response curves for acetylcholine in the absence and presence of D,L-homocysteine were determined at 15 min intervals. Each dose of acetylcholine was allowed to produce its full effect ( $15 \pm 3 \mathrm{~s}$ contact) before the concentration of the drug in the bath was increased in geometric progression by ratio two. Each experiment was separated from the other by at least two washes, in order to obtain the same baseline. Responses from each experiment were demonstrated as amplitude of the contraction shown as $\mathrm{mg}$ of tension. Subsequent concentrationresponse curves were drawn and the $\mathrm{EC}_{50}$ values (the concentration producing a $50 \%$ maximal contractile effect) were determined for both groups by the Hill transformation: $\log \mathrm{E} / \log (\mathrm{Emax}-\mathrm{E})$ versus $\log$ concentration.

To determine the involvement of $\mathrm{NO}$ and potassium channels on D,L-homocysteine effects on duodenal contractions, segments were exposed to NOS inhibitor L-NAME (N-nitro-L-arginine methyl ester) $10 \mu \mathrm{mol} / \mathrm{L}$ and $\mathrm{K}$-channels blocker TEA (Tetraethylammonium chloride) $10 \mathrm{mmol} / \mathrm{L}$.

\section{Measurement of acetylcholinesterase activity}

Acetylcholinesterase activity was determined by Ellman's method. The incubation mixture contained duodenal homogenate in phosphate buffer $(\mathrm{pH}$ 8.0). The mixture was incubated at $37^{\circ} \mathrm{C}$ for 10 minutes. Acetylcholine iodide and 5,5'-dithionitrobenzoic acid (DTNB), used as substrates, were added, and the reaction was started. The reaction was monitored spectrophotometrically (Gilford Instrument, Model 250) by an increase in the absorbance $(\Delta \mathrm{A})$ at $412 \mathrm{~nm}$. An assay, without the tissue homogenate, was used as a blank probe. The measurements were assessed with double probes, and the specific AChE activity was presented as $\mathrm{U} / \mathrm{mg}$ protein. 


\section{Index of lipid peroxidation measurement}

Lipid peroxidation level was estimated by measurement of thiobarbituric acid reactive substances (TBARS) in the tissue according to the fluorimetric method by Yagi [32]. The pink chromogen produced by the reaction of thiobarbituric acid with lipid peroxidation products such as malondialdehyde (MDA) was estimated using 1,1,3,3-tetraethoxypropane as standard MDA. The absorbance of clear supernatant was measured against reference blank at $535 \mathrm{~nm}$. Results were expressed as $\mu \mathrm{mol} / \mathrm{mg}$ proteins.

\section{Tissue total antioxidant status (TAS)}

TAS was measured on Ultrospect 2000 Analyzer with Randox reagent set (Randox). The determination was based on the reaction of 2,2-azino-di-(3-ethylbenythiazoline sulfonate) $\left(\mathrm{ABTS}^{+}\right.$) with peroxidase (metmyoglobin) and $\mathrm{H}_{2} \mathrm{O}_{2}$ to produce the radical cation $\mathrm{ABTS}^{+}$[33]. The ABTS radical cation $\left(\mathrm{ABTS}^{+}\right)$was produced by reacting ABTS stock solution with a $2.45 \mathrm{mM}$ potassium persulfate (final concentration) and incubating the solution in the dark at room temperature for 12-16 h before use. Trolox (a Vitamin E analogue) standards (Calbiochem) were prepared in PBS over the range $0-15 \mu \mathrm{M}$. For the standardization of the starting point of all assays and standards, a $10 \mu \mathrm{l} \mathrm{sample} /$ Trolox standard was added to $1 \mathrm{ml}$ ABTS \pm solution $\left(\mathrm{A}_{734} \mathrm{~nm}=0.700\right.$ $\pm 0.020)$ and an absorbance reading taken exactly 1 min after initial mixing until the decrease in absorbance ceased. Antioxidant activity was expressed as mmol Trolox/ mg protein).

\section{Catalase assay}

Catalase (CAT) activity was determined spectrophotometrically according to Aebi et al. [34]. This method was based on the disappearance of $\mathrm{H}_{2} \mathrm{O}_{2}$ at $240 \mathrm{~nm}$ in the reaction medium containing $30 \mathrm{mM} \mathrm{H}_{2} \mathrm{O}_{2}, 50 \mathrm{mmol} / \mathrm{L}$ potassium phosphate buffer $\mathrm{pH} 7.0$ and $0.1 \mathrm{ml}$ sample. Catalase activity was expressed as $\mathrm{U} / \mathrm{mg}$ protein.

\section{Determination of superoxide dismutase (SOD) activity}

The activity of SOD was measured as the percent of inhibition of epinephrine autooxidation under base conditions by tissue sampling. The activity of total SOD was measured kinetically, as the change of extinction in time (10 minutes) at $480 \mathrm{~nm}$ wavelength [35]. The reaction mixture contained Na-bicarbonate buffer $(50 \mathrm{mmol} / \mathrm{L}$, $\mathrm{pH} 10.2)$ and epinephrine $(0.5 \mathrm{mmol} / \mathrm{L})$ and $0.1 \mathrm{ml}$ of the sample; the reaction started by adding $0.1 \mathrm{ml}$ of epinephrine solution $(0.01 \mathrm{M}$ into $0.01 \mathrm{M} \mathrm{HCl})$. Change of extinction of the same reaction mixture into which $0.1 \mathrm{ml} 0.01 \mathrm{M} \mathrm{HCl}$ was added was used as a blind trial relative to which the inhibition was calculated. Activity of SOD was presented as $\mathrm{U} / \mathrm{mg}$ of protein. 


\section{Determination of GPx activity}

Glutathione peroxidase (GPx) determination was based on oxidation of reduced GSH with GPx using NADPH in reaction catalyzed by enzyme glutathione reductase (GR). Decrease of absorbance at $340 \mathrm{~nm}$ as a result of used $\mathrm{NADPH}+\mathrm{H}^{+}$represents the measure of GPx activity in coupled reaction with GR [36].

\section{Protein content}

The protein content of the samples was determined by the method of Lowry et al. [37] using bovine serum albumin as standard.

All chemicals were obtained from Sigma (Sigma Chemical Co., St. Louis, MO, USA).

\section{Statistical Analysis}

Results were analyzed by standard statistical methods, expressed as mean \pm standard error of the mean (SEM), and graphically presented (Statistical program GraphPad Prism 6). Significance of the differences between the experimental and control groups was determined by Student's t-test and Two way ANOVA. P values below 0.05 were considered statistically significant.

\section{Ethical Considerations}

The ethics protocol was approved by The Laboratory Animals Maintenance and Usage Committee of the Faculty of Medicine, Belgrade University.

\section{RESULTS}

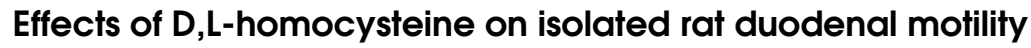

The values of tone, amplitude and frequency of spontaneous contractions in longitudinal smooth muscle segments from the rat duodenum in Tyrode solution are shown in Table 1. Two hours incubation in D,L-homocysteine significantly enhanced the tone, amplitude and frequency of spontaneous contractions (Table 1.). The mean values were tested by Student's t- test. The difference was statistically significant $(* * * \mathrm{p}<0.001)$.

Table 1. Effects of D,L-homocysteine on the tone, amplitude and frequency of isolated rat duodenum- longitudinal muscle layer. Values are expressed as mean $\pm \mathrm{SE}$. $* * * \mathrm{p}<0.001$, statistically different from the control group.

\begin{tabular}{lccc}
\hline & $\begin{array}{c}\text { Tone }(\mathbf{m g}) \\
(\mathbf{m}) a n \pm S D)\end{array}$ & $\begin{array}{c}\text { Amplitude }(\mathbf{m g}) \\
(\text { mean } \pm \text { SD) }\end{array}$ & $\begin{array}{c}\text { Frequency }(\mathbf{m i n}) \\
\text { (mean } \pm \text { SD) }\end{array}$ \\
\hline Control & $102.9 \pm 2.88$ & $120.3 \pm 2.27$ & $9.81 \pm 0.41$ \\
$\mathrm{Hcy}(0.6 \mu \mathrm{mol} / \mathrm{g} \mathrm{bm})$ & $199.9 \pm 5.88^{* * *}$ & $219.3 \pm 2.29^{* * *}$ & $18.53 \pm 0.53^{* * *}$ \\
\hline
\end{tabular}




\section{Effect of D,L-homocysteine on the contractile response of rat duodenal smooth muscle}

Cumulative concentration-response relationships for acetylcholine-induced contraction in duodenal smooth muscle were determined by addition of acetylcholine (ACh) in successive concentrations increments $\left(10^{-9}-10^{-2} \mathrm{M}\right)$. To determine whether the contractile response of ACh is modified by D,L-homocysteine (D,L-Hcy), cumulative additions of acetylcholine was also performed in the presence of D,Lhomocysteine $(0.6 \mu \mathrm{mol} / \mathrm{g} \mathrm{bm})$. D,L-homocysteine has been added $30 \mathrm{~min}$ prior to acetylcholine. Addition of the sulfur amino acid to the incubation buffer increased the baseline tone. The effects of homocysteine on the cumulative contractile responses of acetylcholine are shown in Figure 1. D,L-homocysteine modified the contractile effect of acetylcholine (Fig. 1.). The concentrations of acetylcholine that produced a half-maximal contraction were significantly different in the presence of homocysteine $\left({ }^{*} \mathrm{p}<0.05\right)$. The EC50 values in the control (ACh) and experimental group (ACh plus $\mathrm{D}, \mathrm{L}-\mathrm{Hcy}$ ) were also calculated and presented in Table 2. The dose response curve was shifted to the right in the presence of D,L- homocysteine.
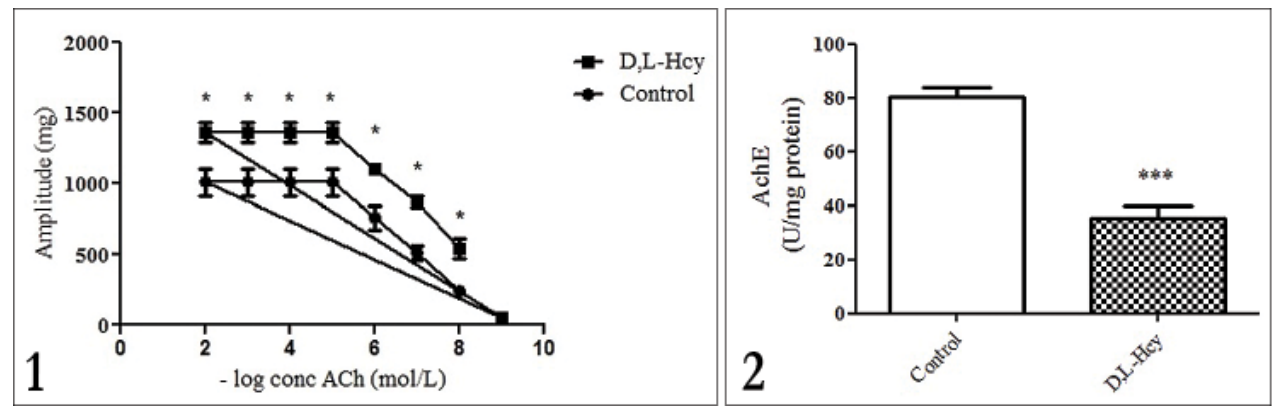

Figure 1. Dose-dependent response of rat duodenal segments to ACh alone (control) and ACh plus D,L-homocysteine (treated with $0.6 \mu \mathrm{mol} / \mathrm{g} \mathrm{D}, \mathrm{L}-\mathrm{Hcy}$ ). Each curve was drawn from the results obtained in six experiments. Ordinate scales show contractions expressed as milligrams of the maximal contractile effect. Vertical lines shows mean $\pm \mathrm{SE} .{ }^{*} \mathrm{p}<0.05$, statistically different from Tyrode; $\# \mathrm{p}<0.05$, statistically different from Homocysteine)

Figure 2. Acetylcholinesterase activity (means \pm SE) in duodenal homogenates in the control group and group treated with D,L-Homocysteine (D,L-Hcy); ${ }^{* * *} \mathrm{p}<0.001$, statistically different from the control

Table 2. Values of EC50 in the control (only ACh) and experimental group (ACh plus D,L-Hcy)

\begin{tabular}{lcc}
\hline EC50 value & Control & D,L-Hcy \\
\hline LogEC50 & -6.624 & -6.827 \\
EC50 & $4.207 \mu \mathrm{M}$ & $6.712 \mu \mathrm{M}$ \\
\hline
\end{tabular}




\section{Acetylcholinesterase activity in homogenized duodenal segments}

The AchE activity determined in homogenized duodenum in the control and experimental group (treated with D,L-Hcy) is presented in Figure 3. Enzyme activity from homogenized tissue of rats treated with D,L-homocysteine was decreased compared to the control group. Moreover, this activity was significantly lower compared to control values for the duodenum (by 55.90\%) (Fig 3.).
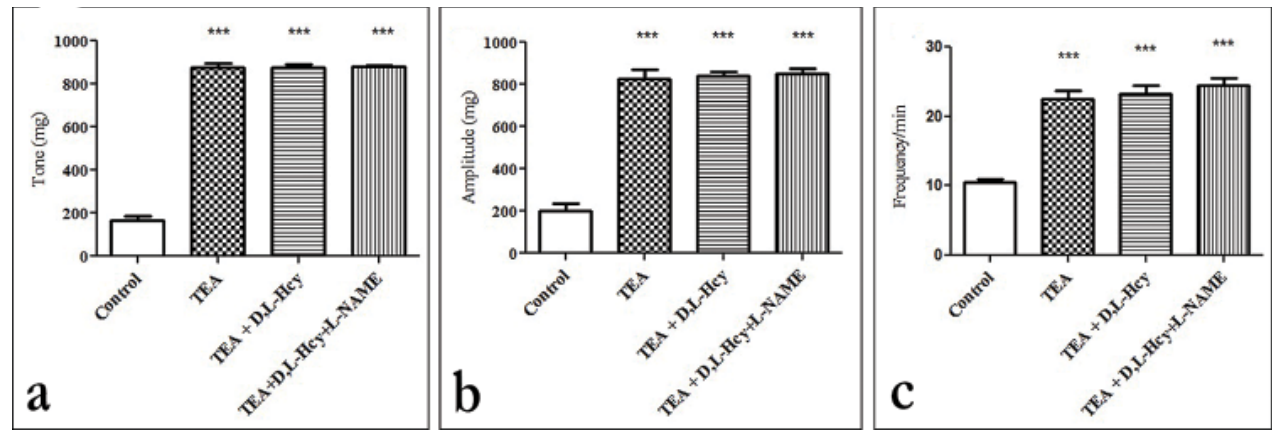

Figure 3. Effects of TEA on tone (A), amplitude (B) and frequency (C) of spontaneous contractions of isolated rat duodenum in Tyrode solution (TEA) and in presence of D,Lhomocysteine (TEA+D,L-Hcy). Values are expressed as mean $\pm \mathrm{SE}$ (statistically different from the control group, $\left.{ }^{* * *} \mathrm{p}<0.001\right)$

\section{Effects of L-NAME on the tone, amplitude and frequency of spontaneous contractions of isolated rat duodenum in the presence of $D, L$-homocysteine and TEA}

Involvement of SDK channels in nitrergic responses was tested by SDK channels nonselective blocker teatraethylamonium chloride (TEA). After $30 \mathrm{~min}$ incubation in the presence of $10 \mu \mathrm{mol} / \mathrm{L}$ TEA, L-NAME $(30 \mu \mathrm{mol} / \mathrm{L})$ was added (Fig. 3.). Effects of L-NAME tone $(p<0.05)$, amplitude $(p<0.05)$ and frequency $(p<0.05)$ of spontaneous contractions of isolated duodenal muscle strips were potentiated in the presence of TEA and D,L-Hcy (Table 3.)

Table 3a. Effects of L-NAME on isolated duodenal contractions in the presence of D,L-Hcy

\begin{tabular}{lcccc}
\hline & Control & Tyrode+L-NAME & D,L-Hcy & D,L-Hcy+L-NAME \\
\hline Tone & $100 \%$ & $376.47 \%$ & $202.63 \%$ & $665.46 \%$ \\
Amplitude & $100 \%$ & $160.02 \%$ & $180.59 \%$ & $355.94 \%$ \\
Frequency & $100 \%$ & $290.55 \%$ & $193.02 \%$ & $366.78 \%$ \\
\hline
\end{tabular}


Table 3b. Effects of L-NAME on isolated duodenal contractions in the presence of D,L-Hcy and TEA

\begin{tabular}{lcccc}
\hline & Control & TEA & TEA+D,L-Hcy & TEA+D,L-Hcy+L-NAME \\
\hline Tone & $100 \%$ & $535.92 \%$ & $578.95 \%$ & $526.66 \% \%^{* * *}$ \\
Amplitude & $100 \%$ & $401.03 \%$ & $411.97 \%$ & $445.53 \% \%^{* * *}$ \\
Frequency & $100 \%$ & $200.11 \%$ & $219.29 \%$ & $253.46 \% \%^{* * *}$ \\
\hline
\end{tabular}

Data are presented as $\%$ of changes compared to control value; $\left.{ }^{* * *} \mathrm{p}<0.001\right)$.

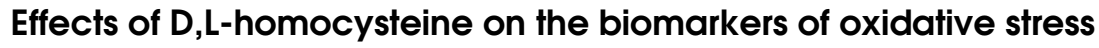 in isolated rat duodenum}

The acute administration of D,L-Hcy induced statistically significant changes in the values of the biomarkers of oxidative stress in the duodenum of rats sacrificed $2 \mathrm{~h}$ after the i.p. injection. Importantly, the activity of the anti-oxidative enzymes (CAT, SOD, GPx) was reduced when compared to the controls (Fig. 4.). Furthermore, lipid peroxidation, as assessed by TBARS production, was increased compared to the control group (Fig. 4). Our results showed a statistically significant decrease of TAS, measured as mmol Trolox/mg protein (Fig. 4).
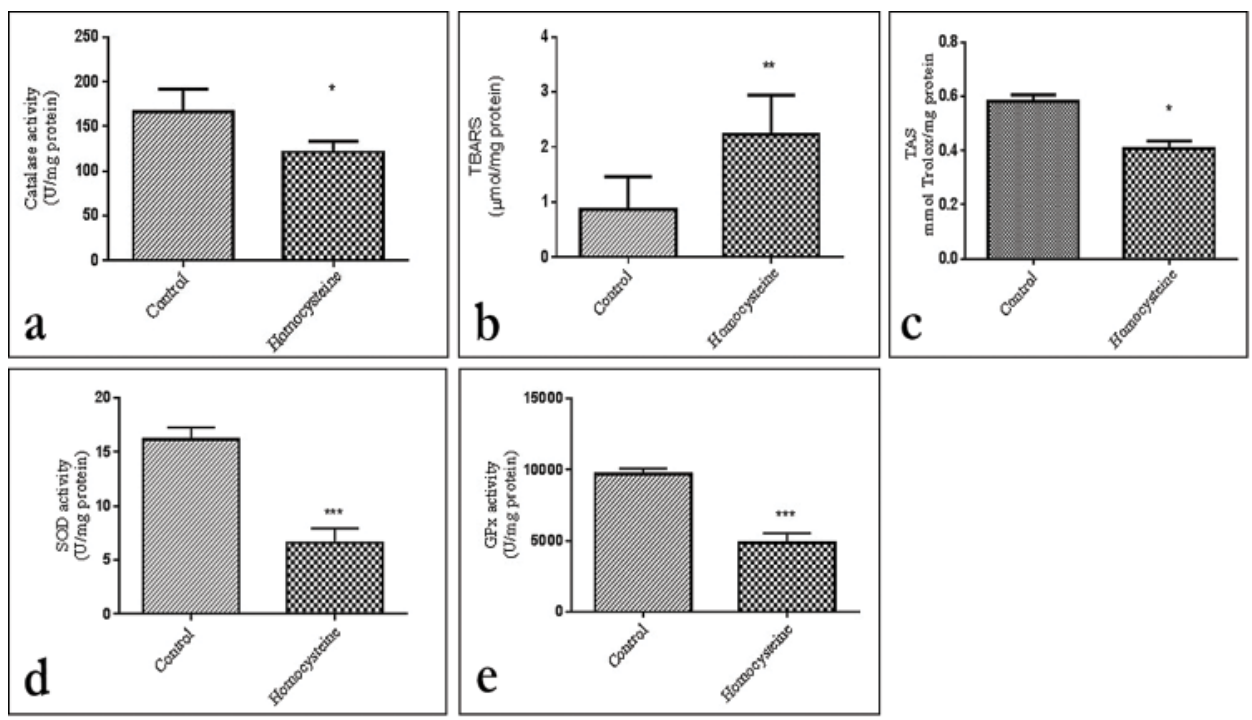

Figure 4. Effects of D,L-homocysteine on activity of catalase (A), TBARS concentration (B), TAS concentration (C), SOD activity (D) and GPx activity (E) (statistically different from the control group; $\left.{ }^{*} \mathrm{p}<0.05,{ }^{* *} \mathrm{p}<0.01,{ }^{* * *} \mathrm{p}<0.001\right)$

\section{DISCUSSION}

The gastrointestinal tract is a significant site of sulfur amino acid metabolism [38]. The gastrointestinal tract accounts for $25 \%$ of whole body transmethylation and 
transsulfuration pathways and is a prominent site of net Hcy release [15]. As reported previously, Hcy has been shown to change intestinal motility, in both a procinetic and inhibitory pattern, acting by modulation of nitrergic innervation or by potassium channels [26,39]. The present study was undertaken to expand upon those initial findings and to assess the effect of D,L-homocysteine on the duodenal motility, especially mechanisms involving nitrergic and cholinergic pathways.

In the experiments reported here, the results indicate an increase in the tone, amplitude and frequency of spontaneous contractions of isolated rat duodenum in D,L-Hcytreated animals versus the control (Tyrode solution). The largest increase was observed in the amplitude of contraction. It has been shown previously that Hcy potentiates the depolarization of murine proximal colon cells, including the increase of the amplitude and frequency of spontaneous contractions of murine colonic stripes [26]. Our results supported this finding. Our previous work [40] showed that D,L-homocysteine thiolactone (D,L-HCT) stimulated duodenal contractility. Choe et al. [41] demonstrated that methionine, the Hcy precursor, enhanced the contractile activity of human colon smooth muscle in vitro. In contrast, $\mathrm{HHC}$ mice model showed delayed intestinal transit due to elevated levels of inflammatory cytokines and increased expression and activity of MMP-9 in colonic mucosa [15]. Although there is proven higher contractility during D,L-Hcy treatment, the mechanism by which D,L-Hcy affects duodenal contractility has not been clearly elucidated. Some of the effects could be achieved by modulating cholinergic or nitrergic innervation. Homocysteine can cause significant endothelial impairment of NO bioactivity [42]. Gastrointestinal smooth musculature is similar to blood vessel muscles, so we investigated how elevated homocysteine levels affect NOmediated and Ach-mediated neurotransmission in the gut.

The present data demonstrated that an acute application of D,L-Hcy intensify acetylcholine-induced contraction of the isolated rat duodenum. The potentiation of ACh-induced contraction by D,L-Hcy in our preparation seems not to be related to a direct agonistic effect of D,L-Hcy on muscarinic receptors, since this sulfur amino acid does not alter the contractile effect of acetylcholine on intestinal smooth muscle, and the effect is mediated through the activation of M2 or M3 receptors [43,44].

The mammalian gut wall contains a distinct class of intrinsic inhibitory motoneurons, the so-called non-adrenergic non-cholinergic (NANC) neurons [45]. These neurons mediate functional relaxations of the gut [46]. NO also regulates the peristaltic reflex of the intestine [47]. At least a portion of the mechanical effect of NO are a consequence of the hyperpolarization of the membrane potential that results in reduced smooth muscle excitability. The most potent inhibitor of NO production is L-NAME [48] which has been used by many investigators to determine the role of nitric oxide in gastrointestinal physiological and pathophysiological conditions.

In our experiments, L-NAME enhanced the tone, amplitude and frequency of the contractions of isolated duodenal muscle strips compared to the control, but after adding D,L-Hcy in the presence of L-NAME, the higher increase appeared. Our 
results suggest that the mechanisms of Hcy action on duodenal contractions are based on the modulation of nitrergic neurotransmission.

Mechanosensitive neural reflexes modulate the contractile behavior and movement of luminal contents in the GI tract [49,50]. Mechanosensitive neurons exist in both the small and large intestines and neural reflexes have been studied in vivo and in vitro [51,52]. Neurotoxins, receptor antagonists, block post-junctional ion channels mediating inhibitory responses depolarize GI muscles, increase action potentials and augment contractions [53,54]. Recent data showed that responses of colonic muscle strips to stretch are superimposed upon ionic mechanisms activated by inhibitory neurotransmitters. Stretch responses require tonic release of NO, but replacement of NO synthesized by neurons is capable of supporting stretch responses. They interpret these findings by considering that mechanosensitive ion channels in post-junctional cells modulate the gain on enteric neural inhibitory input to the colon [55].

Previous studies have shown that SDK channels are blocked by sulfur-containing amino acids, such as L-methionine, and this compound has also been shown to inhibit the SDK channels activated during nitrergic stimulation in murine colonic muscles. According to our results, TEA $(10 \mathrm{mmol} / \mathrm{L})$, a nonselective blocker of $\mathrm{K}$ channels, stimulates spontaneous contractility of longitudinal duodenal muscle layer. Data showed that effects of addition of L-NAME to tissues pre-incubated with D,L-Hcy and TEA (tone, amplitude, frequency) were blocked compared to the effects of L-NAME on segments preincubated in D,L homocysteine alone. We thought that $\mathrm{K}+$ ion channels may modulate the enteric neural inhibitory input to the duodenum. Park et al [26] suggested that spontaneous neural activity and release of NO tonically activated SDK channels. They showed that nitrergic responses to nerve stimulation were reduced by sulfur-containing amino acids. Our data suggest that nitrergic inhibition is mediated, in part, by activation of SDK channels in rat duodenal muscles. The pharmacology of SDK channels is ambiguous at the present time, but new blockers of these channels may be potentially useful in controlling GI motility, particularly in disorders involving organ distention.

In the current study, we tested the hypotheses that homocysteine impairs oxidative stress parameters of the duodenal smooth muscle tissue. In order to verify whether high Hcy levels could alter oxidative status, we evaluated the effect of acute Hcy administration on antioxidant activity in rats.

Our results showed that acute Hcy administration decreased CAT, SOD, GPx activity, suggesting that this amino acid causes a reduction on enzymatic antioxidants in the duodenum. In agreement with our data, other studies suggest a negative correlation between plasma Hcy levels and CAT activity in the liver of rats, pointing a significant reduction of hepatic antioxidant defenses [56,57].

We also investigated the effect of Hcy on the parameters of lipid damage. Lipid peroxidation was assessed by TBARS, which identify malondialdehyde, a final product of peroxidation [32]. Lipid peroxidation serves as a marker of cellular oxidative stress 
and it is recognized as a major causative factor of oxidative damage in gastrointestinal diseases. Results showed that Hcy increased lipid peroxidation in duodenal tissue homogenates. In agreement, data from literature showed that HHC increased superoxide anion production, by $\mathrm{NAD}(\mathrm{P}) \mathrm{H}$ oxidase activation, and peroxynitrite formation, resulting in lipid peroxidation in the liver of rats, which could explain many processes associated with Hcy-induced cell damage including inflammation and apoptosis in liver diseases [56,58]. Furthermore, in our previuos study, it has been demonstrated that TBARS concentrations increased after $3 \mathrm{~h}$ incubation in D,Lhomocysteine thiolactone. We may conclude that duodenal lipid peroxidation appears to be strongly associated to Hcy levels.

Our results showed that Hcy decreased the total antioxidant status of homogenates from the duodenum suggesting that this amino acid causes the acute decrease of nonenzymatic antioxidants in the duodenum. According to literature, patients with diabetes mellitus, cardiovascular disease and gastrointestinal disease, obesity and metabolic syndrome showed decreased level of TAS during chronic exposition to high levels of Hcy [59]. Hyperhomocysteinemia decreased antioxidant defenses, and increased lipid peroxidation in the duodenum of rats, characterizing a reliable oxidative stress.

Taken together, our results presented above qualified the occurrence of excitatory effects of D,L-Hcy on duodenal motility. The present results provide an additional insight into the stimulatory mechanisms of Hcy, and may contribute to explain the complex factors involved in injury exhibited in hyperhomocysteinemic patients: cholinergic stimulation, nitrergic inhibition, potassium channel inhibition and oxidative stress augmentation. So, the therapy of these patients should be complex and include corrections in all potential pathways involved in homocysteine effects on the gastrointestinal tract: antioxidative therapy, new selective blockers of potassium channels and stimulation of production of $\mathrm{NO}$ in nitrergic neurons.

\section{Acknowledgements}

This work was supported by Grant 175043 from Ministry of Science and Technology of Serbia.

\section{Author's contributions}

$\mathrm{DDj}, \mathrm{Lj} \mathrm{S}$, DM conceived of the study, and participated in its design and coordination and helped to draft the manuscript. MS performed research, drafted the manuscript. MS,MDj carried out biochemical analyses. VŠ, TŠ contributed new analytic tools. RŠ, SI analyzed data. All authors read and approved the final manuscript.

\section{Declaration of conflicting interests}

The author(s) declared no potential conflicts of interest with respect to the research, authorship, and/or publication of this article. 


\section{REFERENCES}

1. Finkelstein JD. Pathways and regulation of homocysteine metabolism in mammals. Semin Thromb Hemost. 2000;26(3):219-225.

2. Han L, Wu Q, Wang C, et al. Homocysteine, ischemic stroke, and coronary heart disease in hypertensive patients: A population-based, prospective cohort study. Stroke. 2015;46(7):1777-1786.

3. Chao MC, Hu SL, Hsu HS, et al. Serum homocysteine level is positively associated with chronic kidney disease in a Taiwan Chinese population. J Nephrol. 2014;27(3):299-305.

4. Erzin Y, Uzun H, Celik AF, Aydin S, Dirican A, Uzunismail H. Hyperhomocysteinemia in inflammatory bowel disease patients without past intestinal resections: correlations with cobalamin, pyridoxine, folate concentrations, acute phase reactants, disease activity, and prior thromboembolic complications. J Clin Gastroenterol. 2008;42(5):481-486.

5. Oussalah A, Guéant JL, Peyrin-Biroulet L. Meta-analysis: hyperhomocysteinaemia in inflammatory bowel diseases. Aliment Pharmacol Ther. 2011;34(10):1173-1184.

6. Sartor RB. Mechanisms of disease: pathogenesis of Crohn's disease and ulcerative colitis. Nat Clin Pract Gastroenterol Hepatol. 2006;3(7):390-407.

7. Jiang Y, Zhao J, Xu CL, et al. The relationship of methylenetetrahydrofolate reductase G1793A gene polymorphism, hyperhomocysteinaemia and ulcerative colitis. Zhonghua Nei Ke Za Zhi. 2010;49(8):675-679.

8. Morgenstern I, Raijmakers MT, Peters WH, Hoensch H, Kirch W. Homocysteine, cysteine, and glutathione in human colonic mucosa: elevated levels of homocysteine in patients with inflammatory bowel disease. Dig Dis Sci. 2003;48(10):2083-2090.

9. Danese S, Semeraro S, Papa A, et al. Extraintestinal manifestations in inflammatory bowel disease. World J Gastroenterol. 2005;11(46):7227-7236.

10. Akbulut S, Altiparmak E, Topal F, Ozaslan E, Kucukazman M, Yonem O. Increased levels of homocysteine in patients with ulcerative colitis. World J Gastroenterol. 2010;16(19):24112416.

11. Casella G, Bassotti G, Villanacci V, et al. Is hyperhomocysteinemia relevant in patients with celiac disease? World J Gastroenterol. 2011;17(24):2941-2944.

12. Miller JW, Beresford SA, Neuhouser ML, et al. Homocysteine, cysteine, and risk of incident colorectal cancer in the Women's Health Initiative observational cohort. Am J Clin Nutr. 2013;97(4):827-834.

13. Peyrin-Biroulet L, Guéant-Rodriguez RM, Chen M, Bronowicki JP, Bigard MA, Guéant JL. Association of MTRR 66A $>$ G polymorphism with superoxide dismutase and disease activity in patients with Crohn's disease. Am J Gastroenterol. 2008;103(2):399-406.

14. PhelipJM,Ducros V,FaucheronJL,FlourieB, RoblinX.Association of hyperhomocysteinemia and folate deficiency with colon tumors in patients with inflammatory bowel disease. Inflamm Bowel Dis. 2008;14(2):242-248.

15. Givvimani S, Munjal C, Narayanan N, et al. Hyperhomocysteinemia decreases intestinal motility leading to constipation. Am J Physiol Gastrointest Liver Physiol. 2012;303(3):281290.

16. Sturtzel B, Dietrich A, Wagner KH, Gisinger C, Elmadfa I. The status of vitamins B6, B12, folate, and of homocysteine in geriatric home residents receiving laxatives or dietary fiber. J Nutr Health Aging. 2010;14(3):219-223. 
17. Stojanović M, Šćepanović L, Hrnčić D, Rašić-Marković A, Djuric D, Stanojlović O. Multidisciplinary approach to nitric oxide signaling: Focus on the gastrointestinal and the central nervous system. Vojnosanit Pregl. 2015;72(7):619-624.

18. Gally JA, Montague PR, Reeke GN Jr, Edelman GM. The NO hypothesis: possible effects of a short-lived, rapidly diffusible signal in the development and function of the nervous system. Proc Natl Acad Sci U S A. 1990;87(9):3547-3551.

19. Nichols K, Krantis A, Staines W. Histochemical localization of nitric oxide-synthesizing neurons and vascular sites in the guinea-pig intestine. Neuroscience. 1992;51(4):791-799.

20. Nichols K, Staines W, Krantis A. Nitric oxide synthase distribution in the rat intestine: a histochemical analysis. Gastroenterology. 1993;105(6):1651-1661.

21. Nichols K, Staines W, Wu JY, Krantis A. Immunopositive GABAergic neural sites display nitric oxide synthase-related NADPH diaphorase activity in the human colon. J Auton Nerv Syst. 1995;50(3):253-262.

22. Boeckxstaens GE, Pelckmans PA, Bogers JJ, et al. Release of nitric oxide upon stimulation of nonadrenergic noncholinergic nerves in the rat gastric fundus. J Pharmacol Exp Ther. 1991;256(2):441-447.

23. Calignano A, Whittle BJ, Di Rosa M, Moncada S. Involvement of endogenous nitric oxide in the regulation of rat intestinal motility in vivo. Eur J Pharmacol. 1992;229(2-3):273-276.

24. D’Amato M, Currò D, Montuschi P. Evidence for dual components in the non-adrenergic non-cholinergic relaxation in the rat gastric fundus: role of endogenous nitric oxide and vasoactive intestinal polypeptide. J Auton Nerv Syst. 1992;37(3):175-186.

25. Koh SD, Sanders KM. Stretch-dependent potassium channels in murine colonic smooth muscle cells. J Physiol. 2001;533(1):155-163.

26. Park KJ, Baker SA, Cho SY, Sanders KM, Koh SD. Sulfur-containing amino acids block stretch-dependent $\mathrm{K}^{+}$channels and nitrergic responses in the murine colon. Br J Pharmacol. 2005;144(8):1126-1137.

27. Halliwell B. Free radicals and antioxidants: updating a personal view. Nutr Rev. 2012;70(5):257-265.

28. Peyrin-Biroulet L, Rodriguez-Guéant RM, Chamaillard M, et al. Vascular and cellular stress in inflammatory bowel disease: revisiting the role of homocysteine. Am J Gastroenterol. 2007;102(5):1108-1115.

29. McKenzie SJ, Baker MS, Buffinton GD, Doe WF. Evidence of oxidant-induced injury to epithelial cells during inflammatory bowel disease. J Clin Invest. 1996;98(1):136-141.

30. Middleton SJ, Shorthouse M, Hunter JO. Increased nitric oxide synthesis in ulcerative colitis. Lancet. 1993;341(8843):465-466.

31. Forster J, Damjanov I, Lin Z, Sarosiek I, Wetzel P, McCallum RW. Absence of the interstitial cells of Cajal in patients with gastroparesis and correlation with clinical findings. J Gastrointest Surg. 2005;9(1):102-108.

32. Ohkawa H, Ohishi N, Yagi K. Assay for lipid peroxides in animal tissues by thiobarbituric acid reaction. Anal Biochem. 1979;95(2):351-358.

33. Johnstone C, Day JG, Staines H, Benson EE: The development of a 2,2'-azinobis-(3ethyl-benzothiazoline-6-sulfonic acid) radical cation decolourisation assay for evaluating total antioxidant status in an alga used to monitor environmental impacts in urban aquatic habitans. Ecol Indic. 2006;6:280-289.

34. Aebi H: Catalase in vitro. Methods Enzymol. 1984;105:121-126. 
35. Sun M, Zigman S. An improved spectrophotometric assay for superoxide dismutase based on epinephrine autoxidation. Anal Biochem. 1978;90(1):81-89.

36. Günzler WA, Kremers H, Flohé L. An improved coupled test procedure for glutathione peroxidase (EC 1-11-1-9-) in blood. Z Klin Chem Klin Biochem. 1974;12(10):444-448.

37. Lowry OH, Rosebrough NJ, Farr AL, Randall RJ. Protein measurement with the Folin phenol reagent. J Biol Chem. 1951;193(1):265-275.

38. Fang Z, Yao K, Zhang X, et al. Nutrition and health relevant regulation of intestinal sulfur amino acid metabolism. Amino Acids. 2010;39(3):633-640.

39. Karasu E, Sadan G, Tasatargil A. Effects of hyperhomocysteinemia on non-adrenergic non-cholinergic relaxation in isolated rat duodenum. Dig Dis Sci. 2008;53(8):2106-2112.

40. Stojanović M, Šćepanović LJ, Mitrović D, et al. Rat duodenal motility in vitro: procinetic effects of D,L-Homocysteine thiolactone and modulation of nitric oxide mediated inhibition. Arch Biol Sci. 2013;65(4):1323-1330.

41. Choe EK, Moon JS, Park KJ. Methionine enhances the contractile activity of human colon circular smooth muscle in vitro. J Korean Med Sci. 2012;27(7):777-783.

42. Fu WY, Dudman NP, Perry MA, Wang XL. Homocysteine attenuates hemodynamic responses to nitric oxide in vivo. Atherosclerosis. 2002;161(1):169-176.

43. Zhang LB, Horowitz B, Buxton IL. Muscarinic receptors in canine colonic circular smooth muscle. I. Coexistence of M2 and M3 subtypes. Mol Pharmacol. 1991;40(6):943-951.

44. Thomas EA, Baker SA, Ehlert FJ. Functional role for the M2 muscarinic receptor in smooth muscle of guinea pig ileum. Mol Pharmacol. 1993;44(1):102-110.

45. Glasgow I, Mattar K, Krantis A. Rat gastroduodenal motility in vivo: involvement of NO and ATP in spontaneous motor activity. Am J Physiol. 1998;275(1):889-896.

46. Sanders KM, Ward SM. Nitric oxide as a mediator of nonadrenergic noncholinergic neurotransmission. Am J Physiol. 1992;262(3):379-392.

47. Takahashi T. Pathophysiological significance of neuronal nitric oxide synthase in the gastrointestinal tract. J Gastroenterol. 2003;38(5):421-430.

48. Rees DD, Palmer RM, Schulz R, Hodson HF, Moncada S. Characterization of three inhibitors of endothelial nitric oxide synthase in vitro and in vivo. $\mathrm{Br} \mathrm{J}$ Pharmacol. 1990;101(3):746-752.

49. Smith TK, Spencer NJ, Hennig GW, Dickson EJ. Recent advances in enteric neurobiology: mechanosensitive interneurons. Neurogastroenterol Motil. 2007;19(11):869-878.

50. Dickson EJ1, Spencer NJ, Hennig GW, etal. An enteric occult reflex underlies accommodation and slow transit in the distal large bowel. Gastroenterology. 2007;132(5):1912-1924.

51. Spencer NJ, Smith TK. Mechanosensory S-neurons rather than AH-neurons appear to generate a rhythmic motor pattern in guinea-pig distal colon. J Physiol. 2004;558(2):577596.

52. Lundgren O, Svanvik J, Jivegård L. Enteric nervous system.I. Physiology and pathophysiology of the intestinal tract. Dig Dis Sci. 1989;34(2):264-283.

53. Hwang SJ, Durnin L, Dwyer L, et al. $\beta$-nicotinamide adenine dinucleotide is an enteric inhibitory neurotransmitter in human and nonhuman primate colons. Gastroenterology. 2011;140(2):608-617.

54. Keef KD, Anderson U, O’Driscoll K, Ward SM, Sanders KM. Electrical activity induced by nitric oxide in canine colonic circular muscle. Am J Physiol Gastrointest Liver Physiol. 2002;282(1):123-129. 
55. Won KJ, Sanders KM, Ward SM. Stretch-dependent sensitization of post-junctional neural effectors in colonic muscles. Neurogastroenterol Motil. 2013;25(2):101-113.

56. Woo CW, Prathapasinghe GA, Siow YL. Hyperhomocysteinemia induces liver injury in rat: Protective effect of folic acid supplementation. Biochim Biophys Acta. 2006;1762(7):656665.

57. Chanson A, Rock E, Martin JF, Liotard A, Brachet P. Preferential response of glutathionerelated enzymes to folate-dependent changes in the redox state of rat liver. Eur J Nutr. 2007;46(4):204-212.

58. Ji C, Kaplowitz N. Hyperhomocysteinemia, endoplasmic reticulum stress, and alcoholic liver injury. World J Gastroenterol. 2004;10(12):1699-1708.

59. Evelson P, Travacio M, Repetto M, Escobar J, Llesuy S, Lissi EA. Evaluation of total reactive antioxidant potential (TRAP) of tissue homogenates and their cytosols. Arch Biochem Biophys. 2001;388(2):261-266.

\title{
MNOGOBROJNI MEHANIZMI UKLJUČENI SU U STIMULATORNE EFEKTE HOMOCISTEINA NA GLATKU MUSKULATURU DUODENUMA PACOVA
}

\author{
STOJANOVIĆ Marija, ŠĆEPANOVIĆ Ljiljana, MITROVIĆ Dušan, ŠĆEPANOVIĆ \\ Vuk, ŠĆEPANOVIĆ Radomir, DJURIC Marko, ILIĆ Slobodan, ŠĆEPANOVIĆ Teja, \\ DJURIC Dragan
}

Novije studije potvrdile su povezanost hiperhomocisteinemije i gastrointestinalnih oboljenja, mada su i dalje nepoznati direktni efekti homocisteina na gastrointestinalnu reaktivnost. Cilj ovog rada bio je da demonstrira kako homocistein moduliše azot monoksid zavisnu duodenalnu relaksaciju i da li holinergički receptori i $\mathrm{K}+$ kanali imaju uticaja na stimulaciju motiliteta, kao i da ispita da li je oksidativni stres udružen sa efektima homocisteina. Eksperimenti su izvedeni na mužjacima pacova, telesne mase 250-300g. Dve grupe životinja tretirane su i.p. aplikacijom fiziološkog rastvora i D,L-Hcy $(0,6 \mu \mathrm{mol} / \mathrm{g}$ tm). Posle $2 \mathrm{~h}$ inkubacije, duodenalni segmenti su pripremljeni za biohemijske analize i praćenje kontraktilnog odgovora u izolovanom kupatilu sa Tirodovim rastvorom. Praćeni su efekti TEA $(10 \mathrm{mmol} / \mathrm{L})$ i L-NAME $(30 \mu \mathrm{mol} / \mathrm{L})$ na kontraktilnost duodenuma u prisustvu D,L-Hcy $(0,6 \mu \mathrm{mol} / \mathrm{g} \mathrm{tm})$. Povišen nivo homocisteina bio je od ključne važnosti za pogoršanje kontraktilne funkcije, kroz relaksaciju posredovanu azot monoksidom, kao i, delom kroz aktivaciju K+ kanala. Hcy je pokazao direktno promuskarinsko dejstvo, s obzirom na to da je tridesetominutni pretretman duodenuma značajno povećao kontraktilne efekte rastućih koncentracija Ach (10-9-10-2 mol/L). Aktivnost katalaze, superoksid dismutaze, glutation peroksidaze i totalni antioksidativni status bili su sniženi, dok su vrednosti TBARS-a bile povišene. 
Naši rezultati ukazali su na konzistentno oštećenje gastrointestinalnog trakta izazvano sumporovitom aminokiselinom-homocisteinom. Ovo može doprineti, bar delom, objašnjenju mehanizama uključenim u povezanost hiperhomocisteinemije sa gastrointestinalnim oboljenjima u humanoj populaciji. 